\title{
The great Chinese transformation: From the third to the first world
}

\author{
GRZEGORZ W. KOLODKO*
}

TIGER, Transformation, Integration and Globalization Economic Research, Kozminski University, 59 Jagiellonska Street, 03-301 Warsaw, Poland

(C) 2020 Akadémiai Kiadó, Budapest

\begin{abstract}
In the era of irreversible globalisation, the worldwide economic and political rules of play must take into account of the growing importance of China. Rather than fight the country, one should pragmatically cooperate on solving the mounting global problems. Contemporarily, both China should adapt to the external world and the world itself should adapt to China. There is no possibility of imposing on it a model developed elsewhere, especially that these days liberal democracy is experiencing a systemic crisis in many countries. Neither is there a chance to impose the Chinese model on others, though it seems tempting to a country; it is not an exportable 'commodity,' but its elements may prove useful elsewhere. China is not aiming for global domination; instead, it is consistently integrating with the world to maintain its own development. The only reasonable way forward is thorough observation, mutual learning and pragmatic collaboration based on the non-orthodox economic thought.
\end{abstract}

\section{KEYWORDS}

transformation, globalization, economic system, China, Chinism, development, world order

JEL CLASSIFICATION INDICES

F02, H1, N20, 011, P2

\section{THREE WORLDS IN ONE}

The idea of the so called Third World was never clear. In the decades preceding the great postsocialist transition boosted by Poland's political breakthrough of 1989, it was most often

\footnotetext{
*E-mail: kolodko@tiger.edu.pl
} 
assumed, without going into the intricacies of terminology and definition, that the first world is the highly developed capitalism headed by the United States, the second world is the state socialism with the Soviet Union (USSR) at the helm, and the Third World is all the rest - most often the poor and backward countries, in many cases, especially in Africa - ones still shaking off the legacy of colonialism. One would also often refer to this group of countries as developing countries, though in many cases development was not one of their characteristics. In such a triple division, the Third World was characterised by low output and living standards, by a large population and a quick growth thereof. Even back then, one already had to wonder to which world China belonged. Certainly not to the first one, from which it was separated by an unbridgeable gap, but to the second or the third one?

China did not wish to be classified as the 'second world' as it did not accept the 'with the Soviet Union at the helm' formula, while being unable to put itself at its helm. Maybe in the very beginning of the People's Republic of China's (PRC) existence, in early 1950s, it had accepted the Soviet political predominance but later this changed. Curiously, Mao Zedong in the final years of his rule put the USSR in the same group as the USA. In 1974, he said: 'In my view, the United States and the Soviet Union belong to the first world. The in-between Japan, Europe and Canada belong to the second world. The third world is very populous. Except Japan, Asia belongs to the third world. So does the whole of Africa and Latin America' (Mao Zedong 1974). ${ }^{1}$ Of course, the 'Third World' defined this way should have had China at its helm to be able to stand up to the other two worlds and follow its own, only legitimate way towards a better future.

At that time China was already the world's most populated country, inhabited by 22.5 per cent of global population, but it was also one of the poorest countries with a very backward agriculture producing as little as $2.8 \%$ of global output. To realise how extreme the poverty was there, it is enough to be aware that, according to today's poverty measure (USD 3.20 per person a day at purchasing power parity (PPP)), in the initial years of the PRC more than $99 \%$ of the society suffered from it! This was truly a country of paupers. Now the poor people represent less than $1 \%{ }^{2}$ The ambitious Chinese plan to eliminate poverty altogether in 2020 would mean a position where the economy and social policy provide everyone with a net annual income above RMB (renminbi) 2300, an equivalent of USD 324 at the market exchange rate, and of USD 684 at PPP. Unfortunately, the perturbation brought by the Covid-19 outbreak will doubtless delay this historic achievement.

There is a saying I once heard in Africa: 'If you want to go fast, go alone, if you want to go far, go together.' China is showing to all humankind - both the rich and, more importantly, the poor - that one can both go fast and far. In just a lifetime of two generations - between 1979 and 2020, the population figure has risen by $45 \%$, from 970 million to 1.4 billion. In other words,

\footnotetext{
${ }^{1}$ It would be interesting to know where Chairman Mao saw the place of the Central and Eastern European countries in his classification. Probably not in 'Europe' but rather by the Soviet Union's side, so in the 'first world.'

${ }^{2}$ During the four decades of China's market reforms and opening to the world, over 850 million people got out of poverty. However, as many as 373 million people are still living on less than USD 5.50 a day over there, that is below the poverty line set for upper-middle income economies, a category to which China belongs (World Bank 2020).
} 
China increased its output measured with GDP (Gross Domestic Product) the unprecedented 40 times! It is hard to believe but these are the facts. ${ }^{3}$ Considering the purchasing power and its changes, GDP grew from USD 690 billion to nearly 27 trillion. According to the same PPP measure, GDP per capita rose nearly 27 times in this period, exceeding the world average by 6$7 \%$.

As is always the case with such comparisons, we are dealing with a whole lot of methodological issues as there is more than one way to calculate and more than one comparative measure. According to other estimates, China's GDP per capita has risen from just USD 1,600 in 1978 to almost USD 16,000 in 2019, or exactly 10 times. In both cases these are values calculated at constant prices of 2018 but subject to different assumptions and appraisals of changes to the purchasing power, hence the significant differences (Table 1). The author of those alternative estimates, The Conference Board, in particular, believes that the official Chinese data seriously underestimate the historical base or point of reference - income in 1978.

It is hard to miss the almost identical GDP level per capita in the USA in 1978 and in Poland in 2019. If the differences in the level of development and living standards only boiled down to that, the countries would not be so far apart. After all, what are four decades on the long path of history?

According to the World Bank's classification, the developed high-income countries are economies with a GNI per capita of USD 12,375. This time it's not GDP but Gross National Income (GNI), though the two categories are not far apart. For China, GNI is lower than GDP by around 6\% and in 2019-2020 it could be estimated at USD 10,200. Hence, the high-income

Table 1. The value and dynamics of GDP of China, USA and Poland, 1978-2019 (PPP)

\begin{tabular}{|l|c|c|c|c|c|c|}
\hline \multirow{2}{*}{} & \multicolumn{7}{|c|}{ Official data } & \multicolumn{3}{c|}{ Alternative estimation } \\
\cline { 2 - 7 } & 1978 & 2019 & Quotient 2019/1978 & 1978 & 2019 & Quotient 2019/1987 \\
\hline \multicolumn{7}{|c|}{ Total GDP Billion 2018 US\$ } \\
\hline China & 691 & 26,952 & $39.0 \times$ & 1,516 & 21,956 & $14.5 \times$ \\
\hline USA & 7,252 & 20,993 & $2.9 \times$ & - & - & - \\
\hline Poland & 476 & 1,257 & $2.6 \times$ & - & - & - \\
\hline \multicolumn{7}{|c|}{ Per capita GDP 2018 US\$ } \\
\hline China & 723 & 19,387 & $26.8 \times$ & 1,586 & 15,973 & $10.1 \times$ \\
\hline USA & 32,574 & 63,126 & $1.9 \times$ & - & - & - \\
\hline Poland & 13,631 & 32,775 & $2.4 \times$ & - & - & - \\
\hline
\end{tabular}

Sources: The Conference Board Total Economy Database and own calculations.

\footnotetext{
${ }^{3}$ At constant prices of 2010, China's real GDP rose from nearly 290 billion dollars in 1978 to 11.5 trillion in 2019. 'World Bank national account data, and OECD National Accounts data files' (https://data.worldbank.org/indicator/NY.GDP. MKTP.KD?locations=CN; retrieved 11 May 2020).
} 
country status is not far away; all it takes to reach it is a $20 \%$ growth. Once the shock related to the Covid-19 pandemic has been successfully dealt with, this should take three, maybe four years. ${ }^{4}$ And that is how, in merely half a century, between 1974 and 2024, when Mao rightly saw China in the Third World, the country will have moved its economy to the first world. The whole story is far more complicated, because quantity is not all that counts. Sometimes it even counts less than quality.

\section{LONG, LONG TIME AGO ...}

The Chinese path to the 'first world' has a rich and complex history. On a short timeline, it is usually traced back to its opening to globalisation and the attendant liberal economic reforms of Mao's de facto successor, Deng Xiaoping (1904-1997). His famous quip: 'It doesn't matter if a cat is black or white, as long as it catches mice' is truly the quintessence of pragmatism that has informed Chinese market reforms of the past four decades.

A yet shorter timeline starts with the change of narrative during the rule of Xi Jinping, the party's current leader since the end of 2012, and the President of the PRC since the spring of 2013. Deng advised humility and mostly inward orientation, saying in 1990 'hide your strength and bide your time,' whereas $\mathrm{Xi}$ believes that this time has already come, and he is promoting the 'Chinese dream' (Xi 2014) as well as economic and political external expansion. China is moving from the 'peaceful growth' to an 'assertive growth,' as declared in the documents from the 19th National Congress of the CPC. Xi said: 'The path, the theory, the system, and the culture of socialism with Chinese characteristics have kept developing, blazing a new trial for other developing countries and nations to achieve modernization. It offers a new option for other countries and nations who want to speed up their development while preserving independence; and it offers Chinese wisdom and a Chinese approach to solving the problems facing mankind' (China Daily 2017: 8). He quite unequivocally declared: 'It is time for us to take centre stage in the world and to make a greater contribution to humankind' (Financial Times 2017).

On a very long timeline of the past, the situation varied. At times China was closer to more developed countries and economies, occasionally even leading the world, some other times the distance was growing and sometimes it was even lagging far behind. Leaving aside ancient times - the highly developed civilisation of Confucius era (551-479 B.C.) - these days there are frequent mentions of great sea voyages of admiral Zheng He (1371-1433), who reached Arabia and the eastern coasts of Africa 600 years ago. Rather than by an expansion akin to the one brought by Columbus's voyages to America, these escapades were followed by an utter retreat, which has been never fully explained. Most probably it was necessitated by the need to focus on the heavy load of internal problems, not by a weird phobia of the then emperor of the Middle Kingdom. Today China has a presence in these regions again and there is no indication of its

\footnotetext{
${ }^{4}$ This may happen but does not have to. Some think that the post-pandemic world will prove much worse for China, which will slow down its growth and greatly lengthen its path to catching up with the richer economies. According to those opinions, the West may isolate itself more, blocking the influx of Chinese capital, slow down the knowledge- and technology-sharing and introduce further trade restrictions. The decline in mutual trust will also affect the West-East relations.
} 
intention to withdraw, quite the contrary. There are those in global politics that would be happy should China's mounting internal problems cause it to take in the sails also this time. That will not happen as this time China is unfurling them to better overcome the difficulties experienced back home by penetrating other parts of the world.

In the late 16th and early 17th century some of the illustrious European minds had high regard for the Chinese achievements, treating them as a sign of higher level of development. Gottfried Leibniz (1646-1716), a German philosopher and mathematician believed that in the field of exact science the West was at the leading edge, while the Chinese surpassed Europeans in 'practical philosophy,' in the way it organised the society where 'laws are beautifully directed towards the greatest tranquillity and order' (Obbema 2015: 18). Leibniz, learning about China from Catholic missionaries returning from there, and living in Germany ravaged by the Thirty Years' War (1618-1648), wished Chinese missionaries would arrive in Europe and dreamt of a new global culture combining the best of China and Europe. Some 300 years have passed; missionaries - now civilian rather than Jesuit ones - imbued with all kind of ideas travel both ways with unprecedented frequency, and yet this longed-for global culture is still far ahead ...

Half a century later, Voltaire (1694-1778), a great philosopher and writer of the Enlightenment, wrote of China with esteem. He was certainly inclined to do so by the background of crisis and chaos prevailing in the pre-revolutionary France. When in 1764 he observed: 'Their empire is the best that the world has ever seen' (op. cit., p. 18), he presumably met with similarly critical reactions to those experienced by today's apologists of the complex Chinese reality. Voltaire even created poems about the Qianlong Emperor (1711-1799), whom he perceived as a Platonic philosopher-king. ${ }^{5}$ By contrast, his contemporary, Montesquieu (1689-1755), treated China as a 'despotic state, whose principle is fear' (Ibid., p. 19). Some Sinosceptics would concur with him also today.

Hard as it is to believe, 200 hundred years ago China produced 32 per cent of global output. It will be easier to understand, however, when we realise that back then the country was inhabited by more people than now in relative terms - 38 per cent of the entire world's population. There were more than three times as much of Chinese people as Europeans; 381 and 122 million respectively. Then there came a period of slowdown and regression. While first Europe, and then North America were gathering momentum as a result of subsequent industrial revolutions, China - not without the help from some empires of Western Europe - descended into stagnation. In the late 19th and early 20th century it was a semi-colonised economy. That 'century of national humiliation' is often recalled today. It is known to all primary school pupils, making them even prouder of their homeland's contemporary achievements and avid for something worthy of being the Chinese dream of the 21 st century.

History never repeats itself to the letter, but sometimes the contemporaries cannot help but be reminded of the past. The Chinese were once already the object of fear, or to be more exact, that of scaremongering, amid a surge of xenophobia. The end of 19th century in both North America and Europe went down in history as the inglorious time of 'Yellow Peril.' It was

\footnotetext{
${ }^{5}$ In our day and age, the lack of such poems can be hardly made up for to the President of the PRC by paeans in his honour written in prose in a dozen or so of the Chinese institutes established 'to study and interpret Xi Jinping Thought on Socialism with Chinese Characteristics for a New Era.' This smacks of cult of personality, which the Chinese leader does not need.
} 
essentially an anti-Asian racism where fear of migrants from the region was deliberately instilled in the local population, and disgraceful racist practices were resorted to, at times, on the grounds of the obvious superiority of the American and European civilisation. In the USA, the Chinese Exclusion Act was enacted in 1882 (repealed only in 1943 and the Senate was kind enough to apologise for it only in 2011). Had it not done it back then, this certainly would not have happened now, with a Republican majority.

Whereas in Europe in the late 19th century the German Kaiser Wilhelm II would fuel the hatred towards the Chinese with the threatening vision of their invading hordes. It was to that end that he sent to his distant cousin, the tsar of Russia Alexander III, a drawing depicting a Chinese dragon trampling over the Christian Europe. The multiple copies of the image had a vast success as contemporarily do some chauvinistic and racist memes.

The inability to go with the creative and pro-development flow of the 19th century industrial revolutions, as well as the social and military shocks of the first half of the 20th century caused China to be incapable, for a couple of generations, of overcoming a systemic economic and political - collapse. China's GDP in mid-20th century, when the PRC was founded, with the Communist Party of China at its helm, represented no more than a meagre $2 \%$ of the global output. This fall - as a fall it was - in the form of a drastic downward slide in just 130 years from a situation where the country produced one third of the global output to producing merely its one-fiftieth, coupled with the immense population it affected, was an unprecedented process.

\section{FROM EVER MORE TO EVER BETTER}

Now, at PPP, China's GDP is back to ca. $20 \%$ of the world's output. Over time, the figure will keep growing; one day reaching again over 30\%, like two centuries ago. This has its obvious determinants and less obvious implications. It is the Chinese political and economic system that has enabled such progress, especially in the period of opening and reforms after 1978 (Halper 2010; Lin 2012; Economy 2018). However, it comes at a huge cost and yields negative consequences that the GDP figures fail to mirror. Particularly acute are the ecological costs in the form of environmental devastation and the immense scale of income inequalities. These two areas - in addition to the need for economic equilibrium especially with respect to finance and trade represent the greatest challenges in the coming decades. Improving the environmental situation and reducing income and wealth differences are the issues of more importance than constantly maximising the rate of the traditionally defined economic growth.

Naturally, the latter cannot be disregarded. After all, it is the value of goods produced and services supplied that provides the material foundations of life and determines the wellbeing. Moreover, maintaining a relative balance on the labour market requires, as can be estimated, at least a 5\% GDP growth rate. The economy needs to absorb each year over a dozen million employees migrating to industry and services located in urban areas. This is one of the conditions for keeping social peace, much more important than catching up with and outpacing others. After all, the reason why China has the policy of fast economic growth in place is not to 


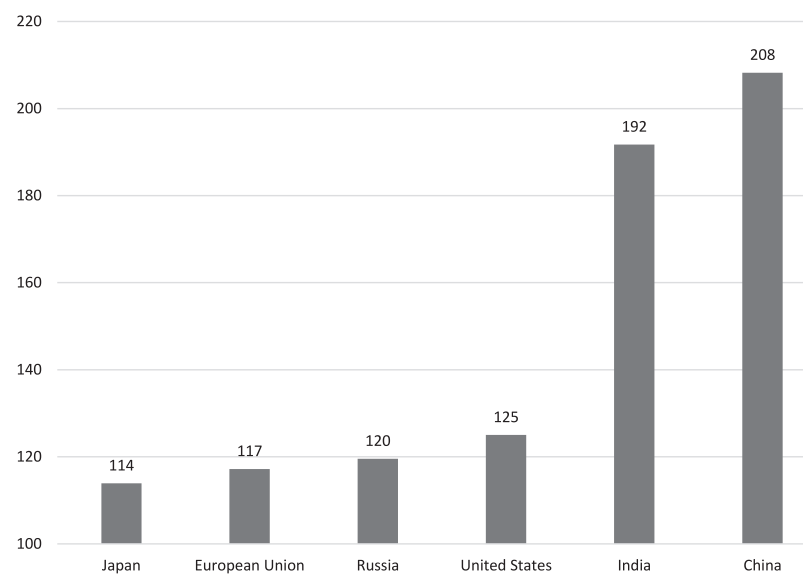

Figure 1. The GDP of China and the Big-5 in 2019 index numbers $(2009=100)$ Source: Own calculations based on the data of WEO (2019).

be able to outdo Japan and the USA in terms of output, but to better satisfy the needs of its gigantic population.

China has picked up speed. Its economic dynamic greatly exceeds that of the highly developed countries, constantly reducing the gap. ${ }^{6}$ What also matters in the context of geopolitics (Malinowski 2019) is that in the second decade of the 21st century India's economy is growing almost just as fast. In the previous 30 years it was not the case, which is of significance for discussions comparing different political and economic models. Between 1980 and 2009, India's GDP rose 7.2-fold, in China, as much as 26.7-fold. In that time, India, which until 1992 had a higher income per capita, was left far behind by China. In turn, while total GDP in China in the decade of 2010-2019 slightly more than doubled, in India it almost doubled. Consequently, now a Chinese person's average income is nearly two and a half times as high as that of an Indian person (Figure 1).

Though we are already living in a beyond-GDP reality (Kolodko 2014; Stiglitz et al. 2018; Koźmiński et al. 2020), let us dwell a while longer on the GDP analysis. It is important because also in this field a lot will change due to the turmoil caused by the Covid-19 pandemic. As a matter of fact, according to the estimates of the IMF (International Monetary Funds), economic growth is still to continue in 2020 in those former Third World's largest two economies, though on a much lesser scale as a result of the lockdown of part of the economy, intended to prevent the spreading of the contagion, and the disruption of the transnational supply and production

\footnotetext{
${ }^{6}$ It is worth comparing, subject to all relevant methodological reservations, the economic dynamic of China with the country of the most successful post-socialist transition, Poland (Piatkowski 2018; Kolodko 2020a). Well, Poland's GDP approximately tripled in the three decades between 1990 and 2019, whereas that of China increased as much as 15 times. Per capita, for Poland this is still more or less three times as much, because the population has slightly decreased, while for China, as we know, the real income per capita has grown approximately 12 times. (For more on the complicated situation in the initial period of Polish transformation, see Kolodko - Rutkowski 1991 and Nuti 2018).
} 
chains (Kolodko 2020b). In the World Economic Outlook (WEO) for spring IMF forecasted for China and India a GDP growth of 1.2 and 1.9\%, respectively, in 2020 and an exponential growth of 9.2 and $7.4 \%$ in 2021 (WEO 2020). ${ }^{7}$ For the highly developed countries a major downturn in output was expected (Table 2).

Should such scenarios materialise, China's GDP at PPP will increase from ca. $128 \%$ of the US level in 2019 to $144 \%$ in 2021 or - reversing the perspective - the US income will decrease from 78 to $70 \%$ of that of China. This is indisputably not the effect desired by the President Donald Trump, whose policy is intentionally designed to weaken the Chinese economy relatively and Make America Great Again! in this context. Therefore, the scale of shifts taking place on the global scene is gigantic. Let me just point out that the China's national income estimated this way is only counterbalanced by the sum total of income of the US, Japan and Russia (Figure 2).

China's total national income (PPP-weighted GDP) is more than one-fourth higher than that of the US, whereas at the current exchange rate it is still much, nearly one-third, lower. In 2019, these figures stood at ca. USD 21 trillion and 14.4 trillion. A better and more informative category is income at purchasing power parity as this figure tells us how much it is actually worthy, or, more precisely, what comparable value of goods and services it can be converted into, considering the international price differences. If we were to stick in our analyses to income calculated at the market exchange rate, adopting the simplifying assumption that these countries will maintain post-2020 the average GDP growth rate at the level achieved in the year preceding the Covid-19 pandemic, meaning 2.3 and 6.1\%, respectively, then China's GDP, reaching USD 26 trillion (at constant prices for 2019), will exceed the USA's level in 2030.

What also, and sometimes especially, matters in the global economic cooperation and rivalry for political supremacy is how China's output impacts other countries. It was not until 1995 that China made it to the very end of the list of top 15 global exporters and, just after 18 years, in 2013, it took the lead which it will continue to hold in the foreseeable future. ${ }^{8}$ China's total

Table 2. Forecasts of recession and growth in 2020-2021 (fall/growth of GDP, \%)

\begin{tabular}{|l|c|c|c|}
\hline Country & $\mathbf{2 0 2 0}$ & $\mathbf{2 0 2 1}$ & $\mathbf{2 0 2 1}(\mathbf{2 0 1 9}=\mathbf{1 0 0})$ \\
\hline China & 1.2 & 9.2 & 110.5 \\
\hline India & 1.9 & 7.4 & 109.4 \\
\hline Japan & -5.2 & 3.0 & 97.6 \\
\hline Russia & -5.5 & 3.5 & 97.8 \\
\hline USA & -5.9 & 4.7 & 98.5 \\
\hline World & -3.0 & 5.8 & 102.6 \\
\hline
\end{tabular}

Source: WEO (2020).

\footnotetext{
${ }^{7}$ At the same time, the European Commission forecasted China's GDP growth in 2020-2021 at 1.0 and 7.8\% (EU 2020).

${ }^{8} \mathrm{With}$ the incredible frictions caused by the Covid-19 pandemic and the often chaotic economic policy reactions, it is rather a question of unforeseeable future.
} 


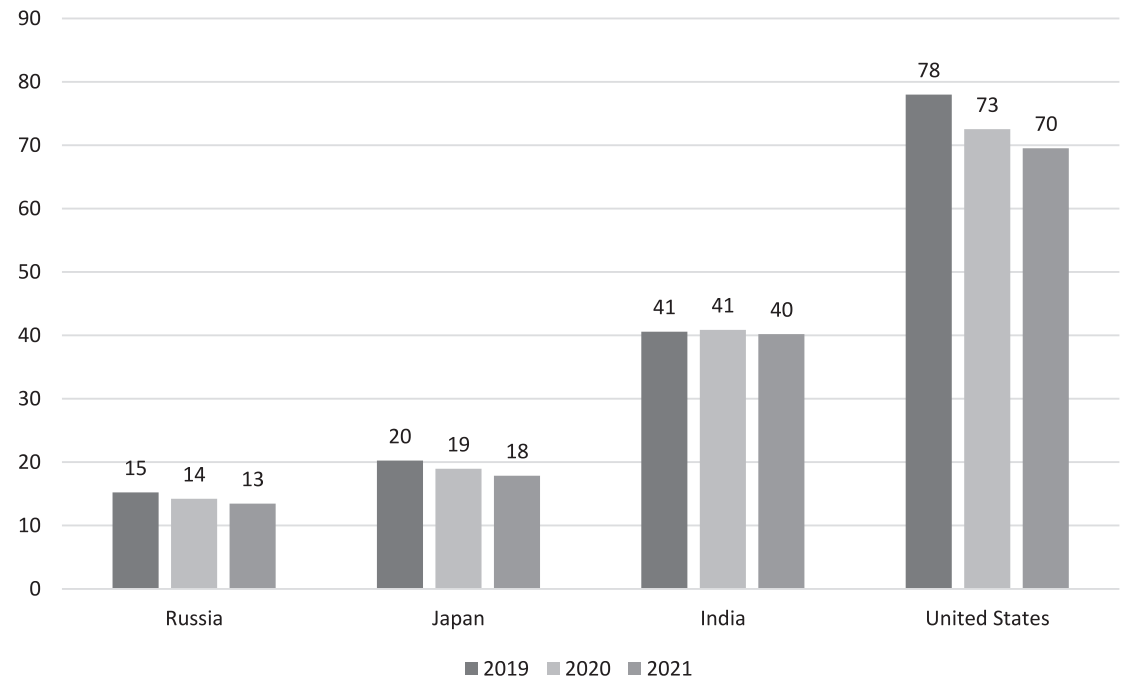

Figure 2. China versus Big-4 GDP of selected countries in per cent of China's GDP Note: In PPP.

Source: WEO (2020).

international trade amounted to USD 4.6 trillion in 2019, with exports up by $0.5 \%$ and imports down by $2.8 \%$ compared to the preceding year (Table 3 ).

Let us also note that the relatively very high exports to Hong Kong are nearly entirely reexported to other countries, all over the world. So, the actual exportation of goods to respective foreign markets is higher than revealed by the data quoted here.

In the last year before the pandemic that shook the world economy, including the international trade, China had a positive balance of USD 421.5 billion, higher than in the preceding year, despite the sanctions resulting from the trade war waged by the USA. China remains the USA's largest trade partner as, regardless of the protectionist restrictions imposed by President Trump's administration, it is the recipient of goods worth over half a trillion dollars, that is one fifth of total US exports.

Another thing that matters in the global rivalry is the state's financial reserves, in which respect China, again, with foreign currency reserves worth the equivalent of USD 3.1 trillion, ranks first worldwide. ${ }^{9}$ These reserves were ca. USD 750 billion higher in 2014, but in the following five years they were sensibly used by financial policy to stabilise the economy and stimulate the output growth. It is worth pointing out here that Beijing holds a third of reserves in the US securities, binding these two economies even further. Two thirds are distributed among other reserve currencies, Euro having the greatest share, tailed by Yen, Hong Kong Dollar, ${ }^{10}$

\footnotetext{
${ }^{9}$ It is also worth noting that both Hong Kong and Taiwan have reserves well exceeding USD 400 billion. Hence, looking at the so-called Greater China, its currency reserves go up to USD 4 trillion.

${ }^{10}$ Hong Kong dollar, HKD, is de facto pegged to the USD under the currency board regime, so from the macroeconomic perspective both currencies can be treated similarly.
} 
Table 3. Top ten countries of Chinese exports, 2019

\begin{tabular}{|l|c|c|}
\hline & USD bln & $\%$ \\
\hline United States & 418.6 & 16.8 \\
\hline Hong Kong & 279.6 & 11.2 \\
\hline Japan & 143.2 & 5.7 \\
\hline South Korea & 111.0 & 4.4 \\
\hline Vietnam & 98.0 & 3.9 \\
\hline Germany & 79.7 & 3.2 \\
\hline India & 74.9 & 3.0 \\
\hline Netherlands & 73.9 & 3.0 \\
\hline United Kingdom & 62.3 & 2.5 \\
\hline Taiwan & 55.1 & 2.2 \\
\hline
\end{tabular}

Sources: International Trade Centre based on General Customs Administration of China Statistics (Trade Map 2020) and own calculations.

British Pound Sterling, Korean Won, Australian and Canadian Dollars, and Swiss Franc. Approximately USD 100 billion is held in gold. It is the China central bank's large-scale purchases of the latter in recent years that have led to a major increase in the prices of this precious metal.

On the other hand, only ca. $2 \%$ of the global currency reserves are held in the Chinese currency. It can be estimated that other countries' central banks have accumulated in RMB no more than the equivalent of a quarter of a trillion of dollars. That is the current status but it will change and RMB's share of global currency reserves will systematically, though slowly, rise. Undoubtedly, at first at the expense of US dollar, which will also have its political implications. Furthermore, China, provoked by the US hostility and aggressive trade policy that hinders economic development, is consistently setting up a parallel financial system, which will help go around USD-based payment mechanisms (Economist 2020a). Currently, the way the international financial clearing system works means that a vast number of international trade transactions cannot be concluded bypassing USD. This enables the USA to impose severe sanctions on others or blackmail them with a threat of sanctions, which is being experienced by Iran these days and which also threatens to befall on its trade partners.

Sometimes hostile emotions virtually lead to a loss of reason. This is what can be said of prominent representatives of the US political establishment formulating accusations against China and demanding financial compensation for the losses sustained by the US economy as a result of the Covid-19 pandemic. The media have reported on the fantastic idea popularised by sources within the administration that the White House is thinking of cancelling part of the USD 1.1 trillion debt to China to 'punish' the country for the pandemic (Economist 2020b). 'Congressional Republicans such as Sen. Lindsey O. Graham (S.C.) have increasingly demanded the United States “make China pay big time” over the damage' (Washington Post 2020). Senator 
Marsha Blackburn went even further, reaching the absurd, as she 'floated waiving interest payments to China for any holdings of U.S. debt, because they have cost our economy already $\$ 6$ trillion and we could end up being an additional $\$ 5$ trillion hit.' (Ibid.). Such public declarations by major-league politicians are the grist to the mill of xenophobia as if there was not enough of it already. During the electoral campaign, striving for re-election of President Trump, his henchmen are paying for media ads insinuating that 'China is killing our jobs and now, killing our people' (Washington Post, op. cit.). Chinese state-owned media were quick to respond, fanning the nationalist emotions with invectives against Mike Pompeo, the US Secretary of State, calling him 'evil,' 'insane' and a 'common enemy of mankind' (ibidem).

A fascinating though often nasty clash between geo-economics and geopolitics is underway (Kolodko 2020c). Both these mega-processes are interconnected, but - assuming that we manage to avoid the ruinous hot war, which assumption I consistently make - in the world of tomorrow, economic processes will be undoubtedly of crucial importance. Power relations will be determined by how these unfold rather than by subjective desires and ambitions of politicians for whom power and influence are everything, and solving social and economic problems only serves as an instrument of their dominance. From this standpoint, China's relative position in the global arena will continue to grow stronger for many years to come as its economy will grow in both absolute and relative terms, though no longer at the rate it did until recently.

\section{CONCLUSIONS}

China not only does not fall under the rule of 'communism' (Sun - Zhang 2020), but thanks to its unique features continues to grow at an above-average pace. Following the victorious, several decade-long war on poverty, it is in for another war, this time one to protect natural environment. Also, this one can be won over time, and this will prove the conditio sine qua non of the Chinese specific political and economic system - so-called Chinism (Kolodko 2018) - being accepted by next generations. Earlier on, China, and especially its leaders, were unwilling to sacrifice maximising the traditionally defined (in the narrow quantitative terms) economic growth rate. Now, on the eve of being promoted to the group of high-income countries, it must sacrifice the same at the altar of development that is triply sustainable: economically, socially and environmentally. If it manages to do that, it will peacefully win another era on the never-ending path of development.

\section{REFERENCES}

China Daily (2017): Xi Jinping and His Era. China Daily, 18-19 November 2017.

Economy, E. C. (2018): The Third World Revolution: Xi Jinping and the New Chinese State. New York: Oxford University Press.

EU (2020): European Economic Forecast, Institutional Paper 125, May 2020, European Commission, Brussels. https://ec.europa.eu/info/sites/info/files/economy-finance/ip125_en.pdf. accessed 8 May 2020. 
Financial Times (2017): Xi Jinping Signals Departure from Low-Profile Policy. Financial Times, 20 November 2017. https://www.ft.com/content/05cd86a6-b552-11e7-a398-73d59db9e399. accessed 8 May 2020.

Halper, S. (2010): The Beijing Consensus: How China's Authoritarian Model Will Dominate the TwentyFirst Century. New York: Basic Books.

Kolodko, G. W. (2014): The New Pragmatism, or Economics and Policy for the Future. Acta Oeconomica, 64(2): 139-160. http://tiger.edu.pl/aktualnosci/2014/acta-ocevonomica-64-2014.pdf. accessed 10 May 2020.

Kolodko, G. W. (2018): Socialism, Capitalism, or Chinism? Communist and Post-Communist Studies, 51(4): 285-298. http://tiger.edu.pl/CPCS_2018.pdf. accessed 10 May 2020.

Kolodko, G. W. (2020a): Economics and Politics of Post-Communist Transition to Market and Democracy. The Lessons from Polish Experience. Post-Communist Economies, 32(3): 285-305. https://doi.org/10. 1080/14631377.2019.1694604.

Kolodko, G. W. (2020b): After the Calamity: Economics and Politics in the Post-Pandemic World. Polish Sociological Review, 2(210): 137-155.

Kolodko, G. W. (2020c): Chinism and the Future of the World. Communist and Post-Communist Studies, 53(4) (forthcoming).

Kolodko, G. W. - Rutkowski, M. (1991): The Problem of Transition from a Socialist to a Free Market Economy: The Case of Poland. The Journal of Social, Political and Economic Studies, 16(2): 159-179.

Koźmiński, A. K. - Noga, A. - Piotrowska, K. - Zagórski, K. (2020): The Balanced Development Index for Europe's OECD Countries, 1999-2017. Cham, Switzerland: Springer Briefs in Economics.

Lin, J. (2012): Demystifying the Chinese Economy. Cambridge: Cambridge University Press.

Malinowski, G. (2019): China, Geopolitics and Geoeconomics. How Not to Fall into the Trap of Narration? Acta Oeconomica, 69(4): 495-522.

Mao Zedong (1974): Chairman Mao Zedong's Theory on the Division of the Three World and the Strategy of Forming an Alliance Against an Opponent. The Ministry of Foreign Affairs of the Republic of China. https://www.fmprc.gov.cn/mfa_eng/ziliao_665539/3602_665543/3604_665547/t18008.shtml. accessed 7 May 2020.

Nuti, D. M. (2018): The Rise and Fall of Socialism. DOC Research Institute, Berlin. https://doc-research.org/ 2018/05/rise_and_fall_of_socialism/. accessed 9 May 2020.

Obbema, F. (2015): China and the West: Hope and Fear in the Age of Asia. London - New York: I. B. Tauris.

Piatkowski, M. (2018): Europe's Growth Champion: Insights from the Economic Rise of Poland. Oxford New York: Oxford University Press.

Stiglitz, J. E. - Fitoussi, J. P. - Durand, M. (2018): Beyond GDP: Measuring What Counts for Economic and Social Performance. Paris: OECD.

Sun, F. - Zhang, W. (2020): Why Communist China isn't Collapsing: The CCP's Battle for Survival and State-Society Dynamics in the Post-Reform Era. Lanham - Boulder - New York - London: Lexington Books.

The Economist (2020a): The Pandemic is Driving America and China Further Apart. The Economist, 9 May 2020. https://www.economist.com/leaders/2020/05/09/the-pandemic-is-driving-america-andchina-further-apart. accessed 10 May 2020.

The Economist (2020b): There is Less Trust between Washington and Beijing than at Any Point since 1979. The Economist, 9 May 2020. (https://www.economist.com/united-states/2020/05/09/there-is-less-trustbetween-washington-and-beijing-than-at-any-point-since-1979. accessed 10 May 2020. 
Trade Map (2020): Trade Map. Trade Statistics for International Business Development. www.trademap.org/ Country_SelProductCountry.aspx?nvpm $=1 \% 7 \mathrm{c} 156 \% 7 \mathrm{c} \% 7 \mathrm{c} \% 7 \mathrm{c} \% 7 \mathrm{cTOTAL} \% 7 \mathrm{c} \% 7 \mathrm{c} \% 7 \mathrm{c} 2 \% 7 \mathrm{c} 1 \% 7 \mathrm{c} 1 \%$ 7c1\%7c1\%7c\%7c2\%7c1\%7c. accessed 10 May 2020.

Washington Post (2020): U.S. Officials Crafting Retaliatory Actions Against China Over Coronavirus as President Trump Fumes. Washington Post, 30 April 2020. https://www.washingtonpost.com/business/ 2020/04/30/trump-china-coronavirus-retaliation/. accessed 10 May 2020.

WEO (2019): World Economic Outlook, October 2019. IMF, Washington, DC. https://knoema.com/ IMFWEO2019Oct/imf-world-economic-outlook-weo-october-2019. accessed 8 May 2020.

WEO (2020): World Economic Outlook, April 2020: The Great Lockdown. IMF, Washington, DC. https:// www.imf.org/en/Publications/WEO/Issues/2020/04/14/weo-april-2020. accessed 8 May 2020.

World Bank (2020): The World Bank in China. Washington, DC. https://www.worldbank.org/en/country/ china/overview. accessed 7 May 2020.

Xi, J. (2014): The Governance of China. Beijing: ICP Intercultural Press. 